\title{
Decision support system for determining chili land using weighted product method
}

\author{
Ramadiani $^{1}$, Bayu Ramadhani ${ }^{2}$, Zainal Arifin ${ }^{3}$, Muhammad Labib Jundillah ${ }^{4}$, Azainil $^{5}$ \\ ${ }^{1,2,3,4}$ Faculty of Computer Science and Information Technology, Universitas Mulawarman, Indonesia \\ ${ }^{5}$ Faculty of Teacher Training and Education, Universitas Mulawarman, Indonesia
}

\section{Article Info \\ Article history: \\ Received Aug 15, 2019 \\ Revised Nov 15, 2019 \\ Accepted Dec 4, 2020 \\ Keywords: \\ Chili \\ Crop land \\ Decision support system \\ Weighted product}

\begin{abstract}
Chili is one of the most consumed food commodities in Indonesia. Thus, chili is very influential to the economic, also inflation and deflation of an area. In order for the needs of chili to be fulfilled and to be able to export, the production must be increased with one consideration being the selection of the right land. The right land must meet the criteria agreed upon by experts, there is land height, soil $\mathrm{pH}$, nutrient value and ambient temperature. This research aims to create a system to support the decision of chili crop land selection using the weighted product method. By entering land data according to the criteria, the user can easily find out which land has the potential to have a higher suitability for chili plants. The result of this system is in the form of land ranking that can help users decide which land to use for chili cultivation.
\end{abstract}

This is an open access article under the CC BY-SA license.

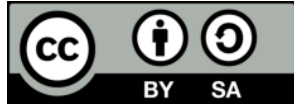

\section{Corresponding Author:}

Ramadiani,

Faculty of Computer Science and Information Technology,

Mulawarman University,

Barong Tongkok Gunung Kelua, 75121, Samarinda, Indonesia.

Email: ilkom.ramadiani@gmail.com

\section{INTRODUCTION}

Economic stability needs to be maintained in a country, so the production and consumption activities in a region should be able to run together consistently so as to create a balance and economic progress in the area. But to maintain economic balance there are many problems that must be faced. One of them is the inflation factor caused by a commodity that is much in demand by Indonesian people, namely chili [1-7]. At certain times in the city of Samarinda, chili will experience an increase in demand on the day of celebration (Eid al-Fitr, Eid al-Adha, New Year, Ramadan and others), so that the supply of local chilies must be increased to maintain inflation stability in the area $[3,8]$. When the supply of local chilies in Samarinda has not been able to meet the demands of the community to the maximum, the Government imported chili from outside, so that it had an impact on increasing inflation in Samarinda especially the prices of soaring chili [9].

In addition to the government, chili farmers as executors who go directly to the field also play an important role in controlling the availability of chili [7-10]. For a more optimal effort for chili farmers, the subjects need a selection system that can be an alternative in facilitating the achievement of production [10]. With the best quality land and large area, it will have a significant impact on increasing the productivity of local chili farmers so that the supply of local chili is always reliable at all times. In addition, by increasing crop land quality selection, it is expected to minimize the use of fertilizers and losses caused by unfavorable land. In this study, we looked for sources to determine the criteria for chili 
crop land in the Agricultural Technology Assessment Agency (BPTP) of East Kalimantan and chili crop land samples at the Agricultural Instructor Center (BPP) Suluh Manuntung.

\section{RESEARCH METHOD}

One of the previous research about decision support system using weighted product is "decision support systems selection of soang superior brood using weighted product (WP) and simple additive weighting (SAW) method" [11]. The results of the study can be concluded that the decision support system for selecting Gurami Soang sires using the WP and SAW method was successfully created. From the 10 alternative data of Gurame Soang sires obtained the results of testing using the WP method get an $80 \%$ accuracy value and Simple Additive weighting gets an accuracy value of $60 \%$. The results showed that the accuracy of the two methods was obtained by the 4 best Gurame Soang broods [11].

Previous research related to this research namely "decision support system for determining chili plantations using simple additive weighting method" is the study that uses simple additive weighting method that can help chili farmers in supporting to determine the chili crop land, where the result is the highest recommended ranking value [3]. The research method used in this study is a qualitative descriptive method. This research is conducted aims to provide information to the farmer. The reason for using this method is because researchers gathered information from several previous studies which explained that the WP method is more accurate in some cases of decision support system research. Next, an analysis of criteria and weighting was carried out to support the experts' decision to select chili crop land. The data collected is processed according to research methods so as to produce conclusions that can be used as recommendations for farmers who want to add to their chili crop lands.

\subsection{Interview}

Interviews were conducted with informants in order to determine the criteria weight which would later be used as a basis for selecting chili crop land and obtaining land samples. The criteria and land samples offered by the two experts, the first is Mr. Wawan Banu Prasetyo as a researcher at BPTP East Kalimantan and the second is Ms. Lediana Helmi as instructor at the BPP Suluh Manuntung Lempake. Interviews were conducted on 7 February 2019 and 6 May 2019 at East Kalimantan BPTP.

\subsection{Observation}

The author will make direct observations when it has finished interviewing the interviewees from East Kalimantan BPTP. This observation was carried out to find values in the height criteria above sea level using the open camera application, while the other three criteria were immediately obtained during an interview with the second interviewees. Observations were made in three places recommended by BPP Suluh Manuntung, all in the Lempake area. The first land (Sumber Rejeki Farmer Group) is located on Jl. Muang In Gg. Puskesmas as shown in Figure 1, the second land (Bumi Putera Farmer Group) is located on J1. Rejo Mulyo and the third land (Cahaya Baru Farmer Group) located on Jl. Muang In Gg. Thailand as shown in Figure 2. The following below are photos of direct observations to the land location.

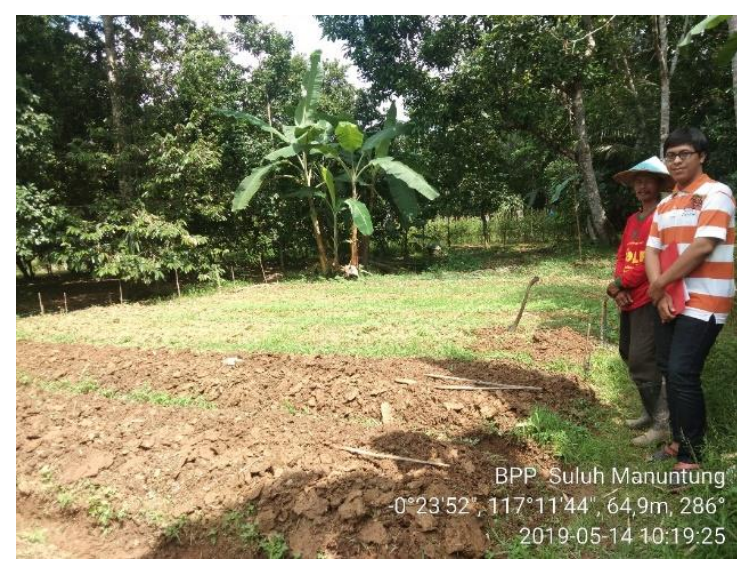

Figure 1. Land of Sumber Rejeki Farmer (A1)

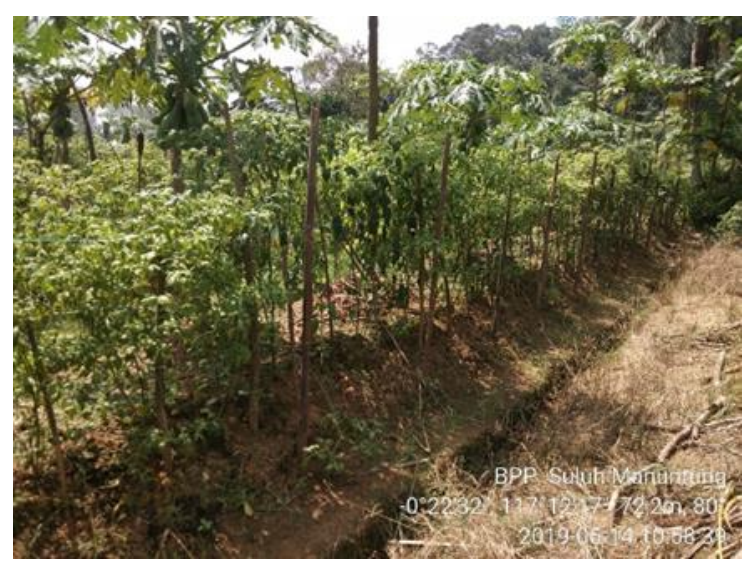

Figure 2. Land of Bumi Putera Farmer (A2) 


\subsection{Weighted product formula}

WP is a multi-criteria decision analysis that is popular and is a method of multi criteria decision making [11]. Like all FMADM methods, WP is a finite set of decisions described in terms of some decision criteria [11-14]. Weighted product methods use multiplication to connect attributes, where the rating of each attribute should be advanced with the corresponding attribute weights [11-18]. This process is similar to the process of normalization. Weighted product calculated based on the rate of interest. Product weghted level of interest method, namely [11-18]:
a. Very unimportant
b. Not important
c. Self-important
d. Important
e. Very important

The process of normalization criteria weight $(\mathrm{W}), \Sigma \mathrm{W}=1$ are:

$$
W j=\frac{W j}{\Sigma W j}
$$

Description: Wj: Weight attribute

$\Sigma \mathrm{Wj}$ : The sum of the weights of attributes

Preference is given to alternatives:

$$
\mathrm{S}_{\mathrm{i}}=\prod_{j=1}^{n} x_{i j}{ }^{w j}
$$

Description:

$\mathrm{Si}=$ Result decisions on the normalization alternative to $-\mathrm{i}$

$\mathrm{X}_{\mathrm{ij}}=$ Rating Alternatives per attributes

$\mathrm{Wj}=$ Weight attribute

$\mathrm{i}=$ Alternative

$\mathrm{j}=$ Attributes

$\Pi^{\mathrm{n}} \mathrm{j}=1 \mathrm{X}_{\mathrm{ij}}=$ Multiplication alternative rating per attribute of $\mathrm{j}=1-\mathrm{n}$

In this alternative where $\Sigma \mathrm{Wj}=1$.

$\mathrm{Wj}$ is the rank of positive value to attribute profits, and negative values to attribute costs. Relative preference of each alternative $(\mathrm{V})$, provided:

$$
\mathrm{Vi}=\frac{\prod_{j=1}^{n} x_{i j}{ }^{w j}}{\prod_{j=1}^{n}\left(x_{j}^{w}\right)^{w j}}
$$

Description:

$\mathrm{V}_{\mathrm{i}}=$ Result alternate preference to - $\mathrm{i}$

$\mathrm{X}_{\mathrm{ij}}=$ Rating alternate per attribute

$\mathrm{W}_{\mathrm{j}}=$ Weight attribute

$\mathrm{i}=$ Alternative

$\mathrm{J}=$ Attributes

$\Pi^{\mathrm{n}}{ }_{\mathrm{j}=1} \mathrm{X}_{\mathrm{ij}}=$ Multiplication alternative rating per attribute

$\Pi^{\mathrm{n}}={ }_{\mathrm{j}}\left(\mathrm{X}_{\mathrm{j}}\right)^{\mathrm{Wj}}=$ the sum of the multiplication result per attribute alternative rating

\section{RESULTS AND DISCUSSION}

\subsection{System description}

Decision support system is a computer-based system that produces a variety of alternative decisions to assist management in dealing with various problems in a structured or unstructured using data and models. To produce a good decision in the decision support system, needs to be supported by quality information and facts, among others: completeness, accuracy, punctuality, Clarity and flexibility. This attribute is related to the degree of adaptation of the information produced to the needs of the various decisions to be taken and against a different group of decision makers [19-25], 


\subsection{System implementation}

This decision support system for determining chili land uses the WP method. This decision support system is web-based, this system produces the highest to lowest value ranking which is used as a benchmark for selecting chili fields in Samarinda City. Users in this system or application are employees who work at Suluh Manuntung BPP, it is shown in Figure 3. On the calculation page, the thing to do is to press all the calculate buttons where the system will calculate the vector $\mathrm{V}$ value of the data. Users can also sort data on the sort button in each column heading. When the compute button has changed to all synchronous, it is time to sort the data according to the best value to worst with the sort button in the $\mathrm{V}$ (rank) vector value column as shown in Figure 4. In addition, there is an add data button to add data and a print button if you want to make a report regarding the results of the calculation of land data (the print button will only appear if all calculations have been completed as shown in Figure 5).

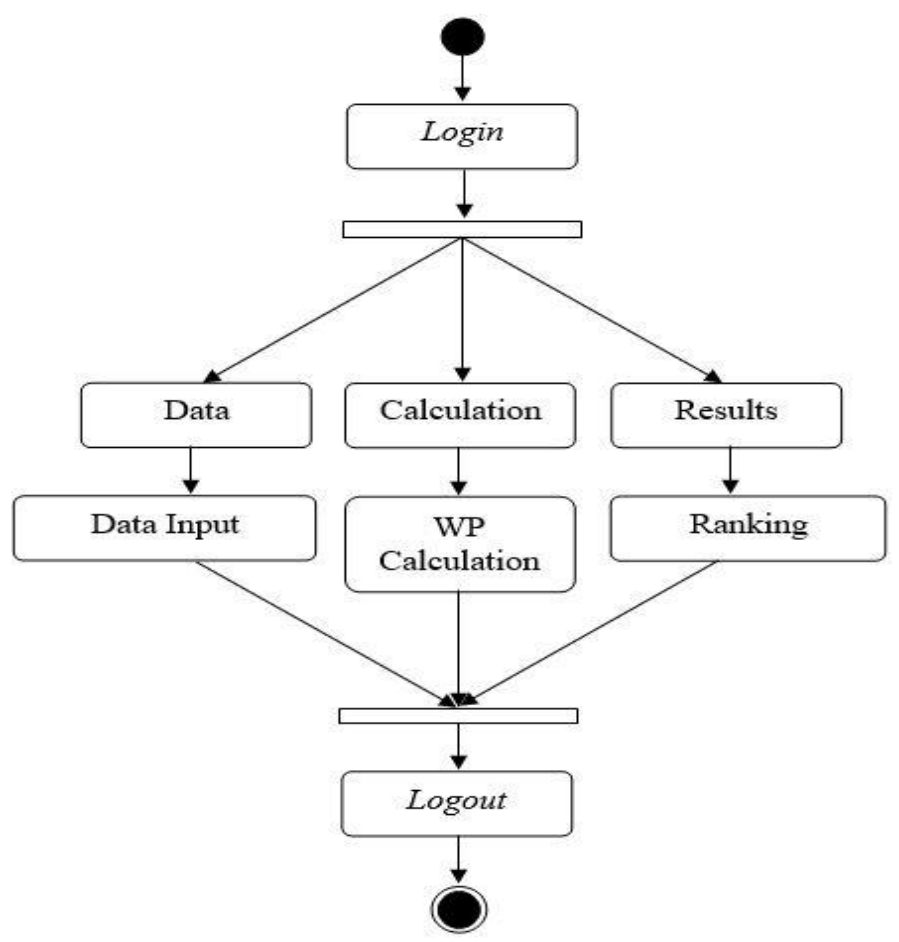

Figure 3. Activity diagram
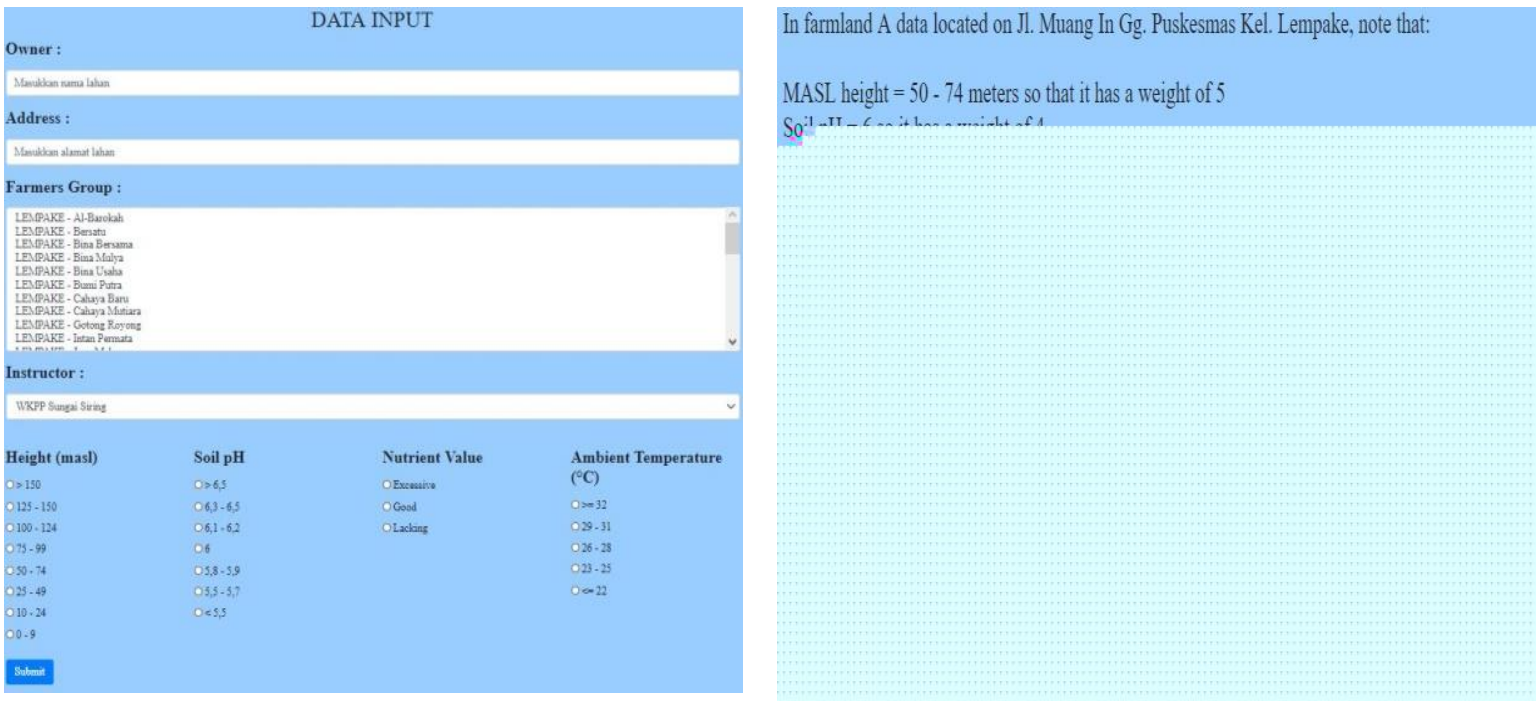

Figure 4. Data input 


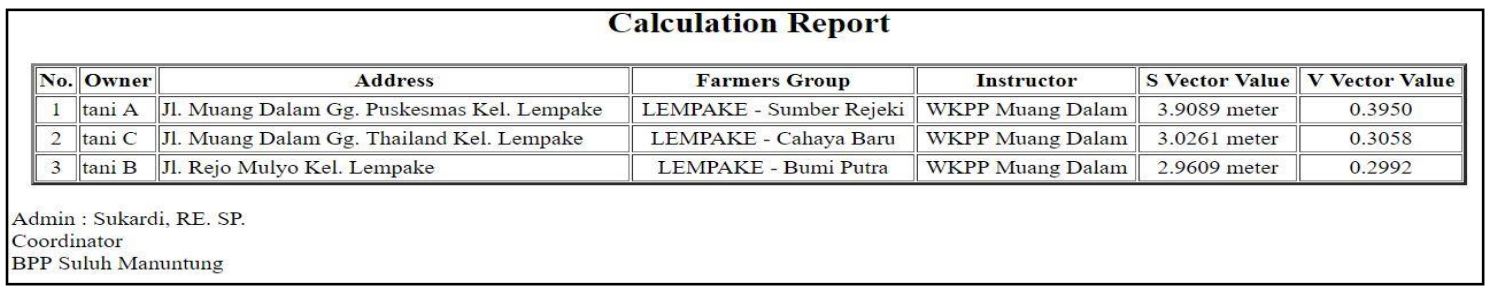

Figure 5. Calculation report

\subsection{Manual calculation system testing}

Trials are conducted to find out whether the application is made in accordance with the objectives. The trial was conducted using manual calculations. Trials were carried out on three chili crop land data which would be selected to determine the results of the land recommendations. It is known that there are three alternative land areas, namely:

A1=Sumber Rejeki Farmer Group

A2=Bumi Putera Farmers Group

A3=New Light Farmers Group

and four land criteria, namely:

$\mathrm{C} 1=$ Altitude above sea level (meters)

$\mathrm{C} 2=$ Soil $\mathrm{pH}$

$\mathrm{C} 3=$ Nutrient Value

$\mathrm{C} 4=$ Ambient Temperature (Celsius)

The details are as follows:

1. Sumber Rejeki Farmer Group (A1)

$$
\begin{aligned}
& \text { C1 }(4 \text { samples })=63.8 \mathrm{~m} \\
& \mathrm{C} 2=\mathrm{pH} 6 \\
& \mathrm{C} 3=\mathrm{OK} \\
& \mathrm{C} 4=27^{\circ} \mathrm{C}
\end{aligned}
$$

2. Bumi Putera Farmers Group

$$
\begin{aligned}
& \mathrm{C} 1(4 \text { samples })=78.67 \mathrm{~m} \\
& \mathrm{C} 2=\mathrm{pH} 5.7 \\
& \mathrm{C} 3=\mathrm{OK} \\
& \mathrm{C} 4=28^{\circ} \mathrm{C}
\end{aligned}
$$

3. Cahaya Baru Farmer Group

$$
\begin{aligned}
& \mathrm{C} 1(4 \text { samples })=70.37 \mathrm{~m} \\
& \mathrm{C} 2=\mathrm{pH} 5.6 \\
& \mathrm{C} 3=\mathrm{OK} \\
& \mathrm{C} 4=29^{\circ} \mathrm{C}
\end{aligned}
$$

The chili land data as shown in Table 1 was partially taken from the Agricultural Extension Center of Suluh Manuntung, one of the fields named Sumber Rejeki Farmers Group as an alternative A1 with an altitude of masl height of 63.8 meters at a preference weight of 5 , a soil $\mathrm{pH}$ of 6 at a preference weight of 4 , has a good nutrient value of the weighted preference value of 3 and environmental temperature 27 of the weighted preference value of 3 . But before heading to the decision matrix, we determine the weighting of each criterion first.

Table 1. Land data table

\begin{tabular}{ccccc}
\hline \multirow{2}{*}{ Alternative } & \multicolumn{5}{c}{ Criteria } \\
\cline { 2 - 5 } & $\mathrm{C} 1$ & $\mathrm{C} 2$ & $\mathrm{C} 3$ & $\mathrm{C} 4$ \\
\hline A1 & $63,8 \mathrm{~m}$ & 6 & Good & $27^{\circ} \mathrm{C}$ \\
$\mathrm{A} 2$ & $78,67 \mathrm{~m}$ & 5,7 & Good & $28^{\circ} \mathrm{C}$ \\
$\mathrm{A} 3$ & $70,37 \mathrm{~m}$ & 5,6 & Good & $29^{\circ} \mathrm{C}$ \\
\hline
\end{tabular}

- Determination of weight 
There are four criteria in this decision support system. The first criterion, height above sea level with weight $=5$. Second criterion, soil $\mathrm{pH}$ with weight $=4$. Third criterion, nutrient value with weight $=3$. The fourth criterion, ambient temperature with weight $=3$.

Criteria for weighting criteria:

$$
W_{j}=\frac{w_{j}}{\sum w}
$$

Total number of weights:

$$
\begin{aligned}
& \sum w=w_{1}+w_{2}+w_{3}+w_{4} \\
& =5+4+3+2 \\
& =14
\end{aligned}
$$

Calculate the value of criteria weights:

$$
\begin{aligned}
& W_{1}=\frac{w_{1}}{\sum w}=\frac{5}{14}=0,35 \\
& W_{2}=\frac{w_{2}}{\sum w}=\frac{4}{14}=0,28 \\
& W_{3}=\frac{W_{3}}{\sum w}=\frac{3}{14}=0,21 \\
& W_{4}=\frac{w_{4}}{\sum w}=\frac{2}{14}=0,14
\end{aligned}
$$

- Determine the value of the vector $\mathrm{S}$ the formula:

After determining the weights, the next step is to calculate the $S$ vector value of each land data using

$$
\begin{aligned}
& S_{\mathrm{i}=} \prod_{j=1}^{n} x_{i j}^{w j} ; \text { with } i=1,2, \ldots, m \\
& S_{1}=\left(5^{0,35}\right)\left(4^{0,28}\right)\left(3^{0,21}\right)\left(3^{0,14}\right)=3,8037 \\
& S_{2}=\left(4^{0,35}\right)\left(2^{0,28}\right)\left(3^{0,21}\right)\left(3^{0,14}\right)=2,8973 \\
& S_{3}=\left(5^{0,35}\right)\left(2^{0,28}\right)\left(3^{0,21}\right)\left(2^{0,14}\right)=2,9598
\end{aligned}
$$

- Ranking by calculating the value of vector $\mathrm{V}$

In this section the final value of a data will be calculated by calculating the value of the vector $\mathrm{V}$ of each land data using (5). The ranking of the best land from the best to the worst is presented in Table 2 .

$$
\begin{aligned}
& \frac{\prod_{j=1}^{n} x_{i j}{ }^{w j}}{\prod_{\mathrm{i}=}^{n}\left(x_{j=1}^{w}\right)^{w j}} ; \text { with } i=1,2, \ldots, m \\
V_{1} & =\frac{3,8037}{9,6608}=0,3937 \\
V_{2} & =\frac{2,8973}{9,6608}=0,2999 \\
V_{3} & =\frac{2,9598}{9,6608}=0,3063
\end{aligned}
$$

Table 2. Ranking results

\begin{tabular}{cc}
\hline Alternative & Ranking \\
\hline A1 & 1 \\
A3 & 2 \\
A2 & 3 \\
\hline
\end{tabular}




\subsection{Black box testing and comparison of calculation result}

System testing is performed using the black box method and comparison of calculation results. black box testing focuses on the functional specifications of the software, the tester can define a set of input conditions and test the program's functional specifications. Stages of testing are carried out to ensure that the system being built is correct, as expected and to facilitate the users in operating it and there are no errors contained therein. Comparative testing of the results of calculations focuses on the accuracy of the results between calculations performed by the system (computer) and calculations manually [11, 19-25]. In this test will compare the results testing how accurate the results are between the two methods of calculation. Therefore, the accuracy between the system calculation and manual calculation of the vector $\mathrm{S}$ value is manual calculation as a denominator in Table 3 [11, 19-25]:

$$
\begin{aligned}
& \frac{\text { Manual Calculation Results for Vector Value of S }}{\text { System Calculation Results for Vector Value of S }} \times 100 \%=\text { Accuracy } \% \\
& \frac{9,6608}{9,8959} \times 100 \%=97,6242 \%
\end{aligned}
$$

Table 3. Comparison of calculation results for vector value of $\mathrm{S}$

\begin{tabular}{ccc}
\hline Alternative & System calculation & Manual calculation \\
\hline A1 & 3.9089 & 3.8037 \\
A2 & 2.9609 & 2.8973 \\
A3 & 3.0261 & 2.9598 \\
Result & 9.8959 & 9.6608 \\
\hline
\end{tabular}

Therefore, the accuracy between the system calculation and manual calculation of the vector $\mathrm{V}$ value is manual calculation as a denominator in Table 4.

$$
\begin{aligned}
& \frac{\text { Manual Calculation Results for Vector Value of S }}{\text { System Calculation Results for Vector Value of S }} \times 100 \%=\text { Accuracy } \% \\
& \frac{0,9999}{1,0000} \times 100 \%=99,99 \%
\end{aligned}
$$

Table 4. Comparison of calculation results for vector value of $\mathrm{V}$

\begin{tabular}{ccc}
\hline Alternative & System calculation & Manual calculation \\
\hline A1 & 0.3950 & 0.3937 \\
A2 & 0.2992 & 0.2999 \\
A3 & 0.3058 & 0.3063 \\
Result & 1.0000 & 0.9999 \\
\hline
\end{tabular}

Thus, the overall accuracy of the comparison of the results of the system calculations and manual calculations on the value of the vector $\mathrm{S}$ and the value of the vector $\mathrm{V}$ are:

$$
\begin{aligned}
& \frac{\text { Accuracy of Vector Value of } S}{\text { Accuracy of Vector Value of } V} \times 100 \%=\text { Accuracy Total } \% \\
& \frac{97,6242}{99,99} \times 100 \%=97,6339 \%
\end{aligned}
$$

\section{CONCLUSION}

The process of making the decision support system for the selection of chili plant land can be carried out by the WP method with predetermined criteria and weights then processed by a web-based system so as to produce an output in the form of a list of the best chili crop land that can be sorted from highest value to value lowest and vice versa. The results of this study are that the chili plantations managed by Sumber Rejeki Farmers Group (A1) have the highest rank compared to two other lands, namely Bumi Putera Farmers Group (A2) and Cahaya Baru Farmers Group (A3). The order from best to worst based on the 
final value of vector $\mathrm{V}$ is $\mathrm{A} 1=0.3950, \mathrm{~A} 3=0.3058$ and $\mathrm{A} 2=0.2992$. Also, based on the results of testing the system calculation method WP with manual calculations, the final results obtained are more or less equal to the accuracy of $97.6 \%$.

\section{REFERENCES}

[1] J. Mariyono, and S. Sumarno, "Chili production and adoption of chili-based agribusiness in Indonesia," Journal of Agribusinessin Developing and Emerging Economies, vol. 5, no. 1, pp. 57-75, 2015.

[2] J. Mariyono. "Impacts seed technology improvement on economic aspect of chili production in central JavaIndonesia," Jurnal Ekonomi Pembangunan, vol. 17, pp. 1-14, 2016.

[3] N. Y. Sari et al., "Decision support system for determining chili plant using fuzzy multiple attribute decision making," International Journal of Engineering and Technology, vol. 7, no. 4, pp. 3556-3562, 2018.

[4] P. Nuvaisiyah, F. Nhita, and D. Saepudin, "Price prediction of chili commodities in Bandung regency using Bayesian Network," Indonesia Journal on Computing, vol.4, pp. 19-32, 2018.

[5] B. I. Ismaya and D. F. Anugrah, "Determinant of food inflation: The case of Indonesia," Bulletin of Monetary Economics and Banking, vol. 21, no. 1, pp. 1-14, 2018.

[6] M. Sativa, Harianto, A. Suryana, "Impact of red chili reference price policy in Indonesia," International Journal of Agriculture System, vol. 5, no. 2, pp. 120-139, 2017.

[7] A. G. Allo, E. Satriawan, and L. Arsyad, "The impact of rising food price on farmers welfare in Indonesia," Journal of Indonesian Economy and Business, vol. 33, no. 3, pp. 193-215, 2018.

[8] O. Attanasio et al., "Welfare consequences of food prices increases: Evidence from rural Mexico," Journal of Development Economics, vol. 104, pp. 136-151, 2013.

[9] N. Hasan, S. Safiai, and N. H. Raduan, "Goal Programing formulation in nutrient management for chili plantation in Sungai Buloh, Malaysia," Advances in Evironmental Biology, vol. 6, no. 12, pp. 4008-4012, 2012.

[10] H. Anggrasari, and J. H. Mulyo, "The trade of Indonesian spice commodities in international market," Argo Ekonomi, vol. 30, no. 1, pp. 13-26, 2019.

[11] Ramadiani et al., "Decision support systems selection of Soang superior brood using weighted product (WP) and simple additive weighting (SAW) method" EDP Sciences, E3S Web of Conferences, vol. 125, pp. 1-9, 2019.

[12] Ramadiani, M. L. Jundillah, Azainil, and R. H. Hatta, "Simple additive weighting to diagnose rabbit disease," E3S Web of Conferences, vol. 31, 2018.

[13] D. W. T. Putra, and A. A. Punggara, "Comparison analysis of simple additive weighting (SAW) and weighted product (WP) in decision support systems," MATEC Web of Conferences, vol. 215, no. 1, pp 1003, 2018.

[14] Oktafianto et al., "Determining housing location using weighted product," International Journal of Engineering and Technology, vol. 7, pp. 3563-3568, 2018.

[15] N. Aminudin et al., "Weighted Product and its application to measure employee performance," International Journal of Engineering and Technology, vol. 7, pp. 102-108, 2018

[16] N. P. Atmojo et al., "Simulation modeling of tablet pcs selection using weighted-product algorithm," Applied Mathematical Sciences, vol. 8, no. 115, pp. 5705-5719, 2014.

[17] M. Wang et al., "A weighted product method for bidding strategies in multi-attribute auctions," Journal of Systems Science and Complexity, vol. 23, no. 1, pp. 194-208, 2010.

[18] Z. Zhiyuan et al., "A weighted adaptation on learning user preference profile," Knowledge-Based System, vol. 112, pp. 114-126, 2016.

[19] Ramadiani, H. R. Hatta, N. Novita and Azainil, "Comparison of two methods between TOPSIS and MAUT In Determining BIDIKMISI Scholarship,” 3rd Int.Conference on Informatics and Computing (ICIC), pp. 1-6, 2018.

[20] Ramadiani, N. Aini, H. R. Hatta, F. Agus, Z. Ariffin and Azainil, "Certain factor analysis for extra pulmonary tuberculosis diagnosis," 2017 4th International Conference on Electrical Engineering, Computer Science and Informatics (EECSI), Yogyakarta, pp. 1-7, 2017.

[21] Ramadiani et al., "Sistem Pendukung keputusan pemilihan tenaga kesehatan teladan menggunakan metode multiattribute utility theory," Jurnal Ilmiah Teknologi Sistem Informasi, vol. 5, no. 1, pp. 1-12, 2019.

[22] Ramadiani et al., "Sistem pendukung keputusan pemilihan pramuka pandega berprestasi menggunakan metode multi objective optimization on the basis of rasio analysis," Jurnal Teknologi Informasi dan Ilmu Komputer (JTIIK), vol. 6, pp. 155-162, 2019.

[23] F. I. Perwitasari et al., "Pemilihan Alternatif simplisia menggunakan metode weighted product (WP) dan metode simple additive weighting (SAW)," J. of Env. Engineering \& Sustainable Technology, vol. 2, pp. 20-30, 2015.

[24] J. A. Sanchez-Molina et al., "Support system for decision making in the management of the greenhouse environmental based on growth model for sweet pepper," Agricultural System, vol. 139, pp. 144-152, 2015.

[25] E. Turban et al., "Decision Systems and Intelligent Systems," Penerbit Andi, Yogyakarta, 2005. 


\section{BIOGRAPHIES OF AUTHORS}
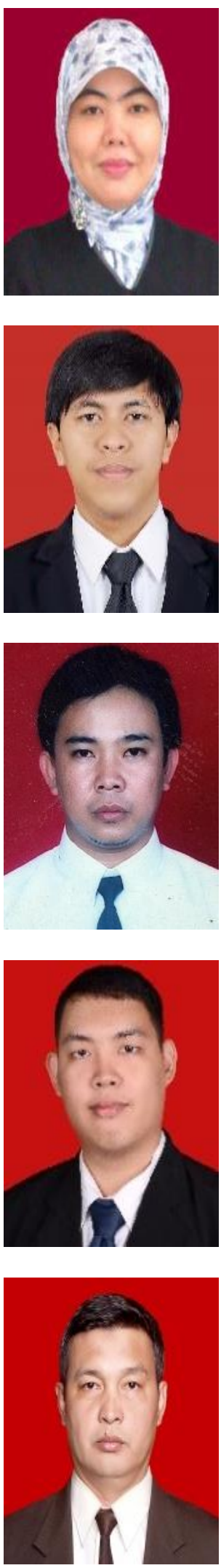

Ramadiani obtained her Ph.D in information system from Univesiti Putra Malaysia (UPM) in 2015. She received her first degree from Mulawarman University (1996), her M.Kom. in Computer Science from Gadjah Mada University (2006). Ramadiani currently works at the Department of Computer Science, Universitas Mulawarman. Ramadiani does research in software engineering, information systems and human-computer interaction. Her current project is 'e-Learning' and decision support system.

Bayu Ramadhani received his bachelor of computer science from Mulawarman University Samarinda Indonesia (2019). His research of interest is decision support system.

Zainal Arifin received his S.Kom from STMIK Widya Cipta Dharma (2003). He received his M.Kom. in Information System from Diponegoro University Semarang (2013). His areas of research interest is information system, decision support system and network security system.

Muhammad Labib Jundillah received his M.Kom. degree in Information System (2019) from Diponegoro University Semarang Indonesia. He obtained his S.Kom from Mulawarman University (2017) Samarinda. His research interests area in information system, decision support system, E-learning, and user statisfication.

Azainil received his first degree from Sriwijaya University (1990), his M.Si from Bogor Agricultural University (2003). He completed his Dr. in education management degree from Jakarta State University in 2012. Currently, he is a senior lecturer at Faculty of Teacher Training and Education, Mulawarman University. His research mainly focuses on education management, management information system, education quality management, information and communication technology, mathematics education. 